\title{
Community college librarians speak out
}

\section{I'm happy to let everyone know what ACRL has meant to me!}

"When sufficient staff was obtained to allow me the flexibility to become actively involved in IACRL and ACRL, I felt that I had finally 'arrived.' What has association with IACRL and ACRL meant to me?

ACRL has given me the courage to keep my goals high and to attain library services for John Wood Community College similar to those at four-year colleges and universi-

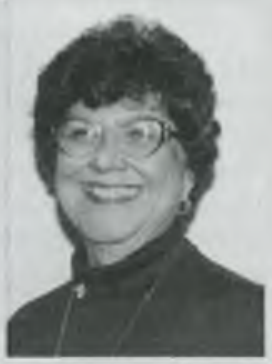

Peggy Shoemake ties. We offer reference, bibliographic instruction, Internet training and access, online cataloging and circulation, and orientation for faculty, staff, and students.

ACRL offered the opportunity to learn from and network with other academic librarians. Since we all strive for the same basic goals (ours are just on a smaller scale), the association has kept me from becoming discouraged and on track.

ACRL librarians have served as a source of inspiration to those of us who work toward achieving academic standards for our community college libraries. My hat is off to the fine work being done by the ACRL librarians."-Peggy Shoemake. director, Learning Resource Center, John Wood Community College, Quincy, Illinois

to cultivate leadership skills at their academic institutions to play a broader leadership role in the Information Age."

For more information contact the ACRL office at $(800) 545-2433$, ext. $3248 / 2510$, or e-mail: althea.jenkins@ala.org or noreen.hale@ala.org.

\section{INSPEC loaded on OCLC's EPIC and FirstSearch}

The Institution of Electrical Engineers (IEE), publisher of the INSPEC Database, and OCLC announced that the entire INSPEC Database backfile will be loaded on OCLC's EPIC and FirstSearch services. More than 2.5 million

\section{Why I'm glad I joined ACRL!}

"As a fairly new technical college librarian, I have found the $\mathrm{CJC}$ listserv to be the most valuable aspect of ACRL membership. I came to this college from a medical library where networking and sharing information are part of claily life. In my position, I felt isolated from other librarians who do what I do until I joined the $\mathrm{CJC}$ listserv. My first day on the listserv, they were discussing staffing

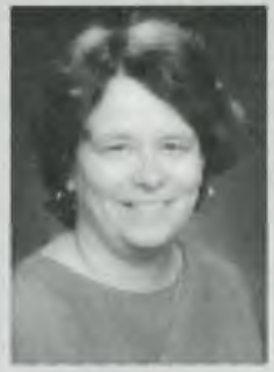

Debi Warner weekend hours in a community college; I was thrilled to talk with folks who had the same problems I do."-Debi Wamer, Librarian, Central Maine Technical College, Auburn

\section{Thank you, ACRL!}

"Mary Ellen (Davis), thank you for your help with my ACRL guideline question. You and the others at ACRL have never failed to help me and never failed to make an appropriate referral."-Barbara Rupp, director of Learning Resources, Trinity Valley' Community' College, Athens, Texas

\section{How you can benefit}

Experience the joy of being part of a professional association: join ACRL. Here's how: call Cynthia Taylor at the ACRL office at (312) 2802521; fax: (312) 280-2520. Participate!

records dating back to 1969 are included in the backfile. INSPEC abstracts and indexes worldwide literature published in the fields of physics, electrical engineering, and computing and control. It currently includes more than five million records.

\section{Attend IS Web forum in San Antonio}

"The World Wide Web As a Teaching Tool" will be the topic of ACRL's Instruction Section's discussion forum at the ALA Midwinter Meeting in San Antonio on Sunday, January 21, 4:30-5:30 p.m. The discussion will focus on ways to successfully use the Web as a teaching 
tool and will be led by Ralph Alberico, Elizabeth Dupuis, and JoAnne Newyear-Ramirez, from the University of Texas at Austin. The discussion leaders will describe how they are using the Web to teach students to find, evaluate, and organize networked information. Participants will have an opportunity to share specific experiences as well as gather techniques and tips to use in instruction sessions at their own institutions

\section{Columbia's Core goes digital}

Columbia's Core Curriculum, which last year marked its 75th anniversary and is thought to be the country's oldest continuous Western Civilization Program, has gone digital. A highquality collection of digital images, available through Columbia's Home Page on the World Wide Web and the Amiens Project (the name given to a range of multimedia materials developed by Gothic architecture expert professor Stephen Murray), are now part of the Art Humanities course in the Core.

The images were made available digitally through the collaboration of the Art History and Archaeology Department, the Columbia University Libraries, and Academic Information Systems.

Students had previously relied on flat, one dimensional slides in class and trips to the library reserve room to consult a limited number of texts or black-and-white prints; now they can view high-quality images in electronic classrooms and study them via the Web from their dorm rooms or computer labs. Approximately 50 percent of the course's images-some 500 slides-are already online.

Hillary Ballon, director of the Art Humanities course, noted that one of the most complicated aspects of the project involves digital property issues including obtaining copyrights from slide distributors and museums. "Because we are on the frontier, we are hitting some stumbling blocks in obtaining permission to put images online."

\section{Correction}

Subscription requests for FUNDLIST, a resource mentioned in "Fundraising: A Se lected List of Internet Resources" (CGRL Neus, November 1995) should now be sent to listproc@listproc.hcf.jhu.edu. The editors regret the error.

\section{Third party e-mail available from UnCover}

Third Party E-Mail, which allows search results to be sent electronically to third party accounts, is now available from the UnCover Company as part of its Customized Gateway portfolio. Third Party E-Mail enables users to capture an UnCover citation and e-mail it to a personal email address, which can be stored in an UnCover profile or a library-designated mailbox.

This capability also enhances UnCover's SUMO (Subsidized UnMediated Ordering) feature, which blocks the ordering of titles owned by the Customized Gateway institution. Libraries can also use SUMO to block ordering of titles with a copyright royalty fee that exceeds a library-specified limit. A library could decide to send citations that are blocked from ordering to its Interlibrary Loan Office via Third Party E-Mail. Contact UnCover for details at (800) 7877979 or uncover@carl.org.

\section{Lewis and Clark selects Ameritech}

Lewis and Clark Community College in Godfrey, Illinois, has entered into a strategic alliance with Ameritech Library Services to provide information management products including Horizon, NetPublisher, InfoShare, and WebPAC.

Lewis and Clark President Dale Chapman said, "We want to have the most advanced technology in the U.S. As a forward-thinking community college, our vision is to empower students and faculty by integrating technology into the learning process to develop life-long education. Our library will play a key role in making this vision a reality."

\section{Joint use library approved}

A library jointly built and operated by Front Range Community College (FRCC) and the city of Westminster, Colorado, has been approved by both the City Council and the Colorado State Board for Community Colleges and Operations.

The college will contribute nearly three million dollars and the city two million. Construction of the 76,000 -square-foot library will be at the west end of the college's main building. If all goes according to schedule, construction will begin next summer and the library will open by late 1997. According to a report in the Rocky Mountain News, the city's portion of the library would encompass about 30,000 square feet, but all patrons would be permitted to use the entire library. 
According to Warren Taylor, director of the Front Range Community College Library, the city had planned to build a library close to where FRCC was planning to build one. He said it made sense to combine libraries as the joint-use library "will have much more space and the students will get a wider range of services and opportunities." Taylor added that there was some cost savings and that more staff would be available than either library could support alone. In addition, the collection would be larger and have a broader range of materials.

\section{Murder mystery raises money at Cal State}

More than 200 amateur sleuths attended a murder mystery in the California State University, Northridge, Library. The drama of blackmail and murder unfolded throughout the entire library building as guests searched for victims, clues, and suspects in the darkened bookstacks and hallways. Dinner was provided with the admission ticket and the guests enjoyed the entertainment as the body count escalated and the red herrings grew more confusing. Many guests found themselves suspects and subject to interrogation or handcuffing. The event, sponsored by the Friends of the Oviatt Library, raised more than $\$ 5,800$ for the library.

\section{Spaceline: New NLM database offered}

SPACELINE, a cooperative venture of the National Library of Medicine (NLM) and the National Aeronautics and Space Administration (NASA), is a database emcompassing space life sciences research.

The database consists of references to journal articles, technical reports, books, book chapters, conference proceedings, meeting abstracts, bibliographies, and audiovisual materials. Sources include NLM databases including MEDLINE journal articles from 1966 on, and thousands of citations from 1961 to the present contributed by NASA. SPACELINE is available to anyone holding a valid NLM user code. Information about how to gain access to the library's on- line network is available from the NLM Public Information Office, e-mail: publicinfo@nlm.nih gov.

\section{Join the leadership discussion}

Keeping with ACRL president Patricia Breivik's theme, "Every Librarian a Leader," the ACRL 1996 President's Program Committee is sponsoring a discussion on opportunities outside of the library available to academic librarians. The discussion will take place during ALA's Midwinter Meeting in San Antonio on Saturday, January 20, 11:30 a.m.-12:30 p.m.

As Breivik says, "there are people who would argue that unless librarians become beyond-library-walls leaders, our collective ability to assist people in meeting their information needs will continue to be diminished-that unless librarians become beyond-library-walls leaders, the Information Age will only broaden the gap between haves and have nots."

The one-hour session will be run as four concurrent poster sessions. Presentations include: Shirley Leung (University of CaliforniaIrvine) will discuss the ACE fellowship program; Richard Shaw (Technical College of the Low Country) will discuss involvement in regional accreditations; Maureen Sullivan or Kathryn Deiss will discuss the Association of Research Libraries' OMS Development Program; and Don Tolliver (Kent State University) will provide an overview of the AAHE Teaching, Learning, Technology Roundtable Initiative.

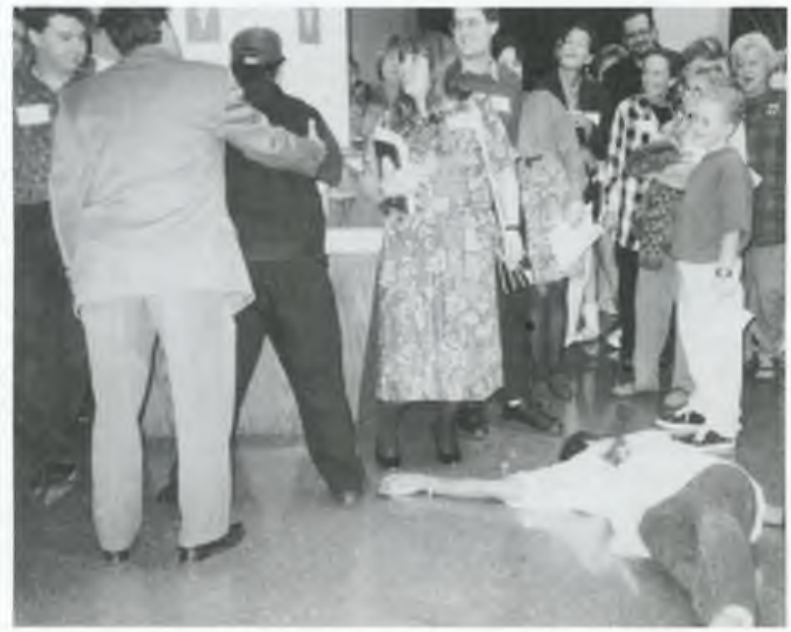

The chief inspector frisks a suspect after the first "murder" in the Oviatt Library at Cal State, Northridge. 